\title{
Antipodes and the Scandal of Particularity
}

\author{
Kenneth D. Keathley \\ in The 72nd Annual Meeting of the Evangelical Theological Society
}

https://doi.org/10.54739/g98q

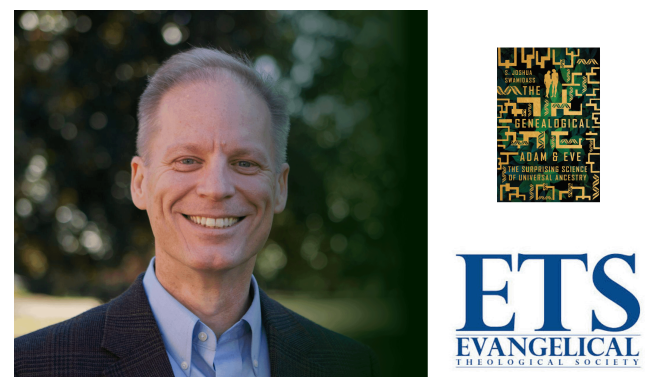

he main concern about the Genealogical Adam and Eve model $(\mathrm{GAE})^{1}$ is its assertion that humans already existed outside the Garden. This can be viewed as another example of the problem of the Antipodes and the scandal of particularity. This dilemma-this theological embarrassment-is the problem of the others, the outsiders-those who appear to be outside the biblical narrative. Their very existence seems to threaten the grandeur of the biblical story and turn it into something parochial. My contention is that there is nothing new about this.

\section{The Twin Particularities}

Gabriel Fackre calls this the "scandal of particularity."2 Christians believe that God was in Christ, reconciling the world to himself. Therefore we proclaim that a particular man accomplished a universal, salvific work. This work was necessary because we also believe that the entire human race was separated from God by the disobedience of one specific man. The Good News is that the last Adam rescues us from the failure of the first Adam (Rom 5:12-21). This claim about these two specific, particular men is indeed scandalous.

Christians generally group the respective impacts of the two Adams under two doctrines. We place the effects of Adam's sin under the heading of "Original Sin." The necessity of responding to the Gospel doesn't have a label that is quite so clear and tidy, so for lack of a better one I'm going to use the Necessity of Explicit Faith, or simply "Explicit Faith." Original Sin and Explicit Faith serve as twin pillars of Christian doctrine. Fackre is correct: they are both sources of great offense, both in and out of the Church. We have only limited conciliar help with these two doctrines, and what guidance we do have in some ways compounds the problems or at least makes them more acute.

We contend, paradoxically, that all humans are responsible for Adam's sin even if they've never heard of the man, while at the same time claiming that, in order to receive the benefits of the second Adam, we must at least hear about him. Let me be clear: I do affirm this paradoxical claim, because I believe it to be the teaching of Scripture (or at least very close to it). But I don't claim to have (satisfying) answers for all the dilemmas this affirmation creates.

\$. Joshua Swamidass, The Genealogical Adam and Eve, 2019.

2. Gabriel Fackre, “The Scandals of Particularity and Universality," Midstream 22:1 (Jan 1983), 32-52.
In his gracious and respectful critique, Hans Madueme rejects the GAE model because in his words, “[It] doesn't adequately address the significance of other pressing realities like the fall, original sin, salvation, and theodicy....."3 Those are indeed significant pressing realities. Madueme describes the question of those outside the Garden as "the elephant in the room," and he specifically asks, "If these biological humans have a different origin from Adam and Eve, do they participate in original sin and salvation? Did Christ live and die for them, and were they able to experience justification by faith?" Ah, "original sin and salvation"-here we see the two scandalous particularities at work. I agree with him that these are indeed difficult questions. But they are not new. His statement could give the impression that the GAE model creates a problem where one did not previously exist. I contend that the opposite is true. The problem of the outsider, the Antipode, is a dilemma that has always been with us. The GAE model did not create this problem, nor does it exasperate this problem, and it perhaps provides some new ways of examining this problem. I believe that at this point it should not be dismissed out of hand.

Christians generally have been willing to affirm the truthfulness of both Original Sin and Explicit Faith while at the same time recognizing that we have not been able to successfully explicate all the implications or resolve all the scandalous dilemmas that arise. I suggest that the theological problems with the GAE model concerning Original Sin and Explicit Faith are similar to those historically associated with the existence of Antipodes. The problems are not identical, but they are close enough to be placed in the same orbit.

\section{We've Been Here Before}

The early Church handled the problem of Antipodes by simply denying their existence. This is not because they believed the earth was flat. By and large, the early Church Fathers had little trouble with belief in a spherical earth. There were some, such as Lactantius and Cosmas, who rejected the notion that the earth was round. ${ }^{4}$ But they appear to have been in the minority. Most seem to have agreed with Augustine, who affirmed that the earth is a globe. This is not all that surprising, since the Ptolemaic cosmology was the reigning paradigm of that day. Ptolemy's model presents the heavens as concentric rings revolving around a spherical earth. No, what the early Fathers

3. Hans Madueme, "Evolution and Historical Adam? A Provocative but Unconvincing Attempt," The Gospel Coalition (March 2, 2020).

https://www.thegospelcoalition.org/reviews/genealogical-adam-eve-swamidass/ (Accessed 11/12/20).

4. Lactantius, Divine Institutes, 3.24; and Cosmas, Christian Topography, Book 4 
uniformly rejected was the notion that people lived on the other side of the earth. Why was there such opposition to Antipodes? Two reasons: first, at that time their existence could be legitimately viewed as an open question. The Church Fathers, with few exceptions, considered the question to be unanswerable and therefore they dismissed it as irrelevant. But the second and more important reason was that to admit their existence was to open a theological can of worms.

\section{From Augustine to Columbus}

In Book 16 of his The City of God, Augustine addresses the issue directly: "As to the nonsense about there being Antipodes, that is to say, men living on the far side of the earth, where the sun rises when it sets for us, men who have their feet facing ours when they walk-that is utterly incredible." ${ }^{5} \mathrm{He}$ argues that, though the earth is round, it is impossible that people live on the far side of it. He explains that "first, our Scriptures never deceive us" and "second, it is utterly absurd to say that any men from this side of the world could sail across the immense tract of the ocean, reach the far side, and the people it with men sprung from the single father of all mankind." 6 Note that Augustine's objection is primarily theological, based on his conviction that Adam is the sole progenitor of the human race.

Medieval and Renaissance scholars almost unanimously agreed with Augustine: the world is round but Antipodes don't exist. This viewpoint can be found from Isidore of Seville's encyclopedia to the writings of Thomas Aquinas. ${ }^{7}$ In his Disputed Questions on Truth, Thomas Aquinas develops a thought experiment to address the question of the fate of the unevangelized. ${ }^{8}$ He affirms the necessity of Explicit Faith, but he also considers the unevangelized to be inculpable for their ignorance. He makes clear that he doesn't really believe that there are any unreached people left to evangelize.

Aquinas was convinced that the whole world had at least heard about Jesus. In fact, both Augustine and Aquinas pointed to the universal acceptance of the Gospel as evidence of its truthfulness. ${ }^{9}$

As Aquinas formulates his thought experiment, he does not even consider the possibility of Antipodes. The faithful received the good news while heretics, Jews and Muslims had rejected it. The only remaining person hypothetically possible was "someone brought up in the forest or among wolves." If such a person existed and responded to the light of general revelation, Aquinas reasoned that God would send a preacher like he sent Peter to Cornelius. So from Augustine to Aquinas the majority view appears to be that Antipodes do not exist.

5. Augustine, The City of God, 16.9

6. Ibid.

7. Isidore, Etymologies, 9.2.133; 14.5.17

8. Aquinas, Disputed Questions on Truth, q.14.1; q.14. a.1 ad. 1.

9. William Lane Craig, “'No Other Name': A Middle Knowledge Perspective on the Exclusivity of Salvation through Christ," Faith and Philosophy 6:2 (April 1989): 174.
When Columbus proposed his westward sea journey, the Spanish rulers called together a committee to consider his proposal. The committee recommended against sponsorship, not on the grounds that the earth is flat, but because (among other reasons) "there could not be inhabitants on the other side because they would not be descended from Adam."10

So concerning Antipodes, avoidance and dismissal were historically the Church's modus operandi. There's some evidence of avoidance going on today. Consider a recent book, Adam, the Fall, and Original Sin: Theological, Biblical, and Scientific Perspectives. ${ }^{11} \mathrm{I}$ found this to be a very helpful work in which I was in overall agreement. Several authors provide chapters of careful theological thought based on a close reading of Scripture. But at various places the writers decline to interact with the pertinent scientist issues, and instead refer the reader to the scientific section of the book. ${ }^{12}$ However, only one chapter actually addresses the scientific evidence, and that simply as a survey. The conclusions reached by the anonymous scientific author appear to be incompatible with what many of the biblical scholars argued, and no real attempt is made to reconcile this incongruity. They seem to dodge the question. However, just as the Church was eventually forced to confront the existence of Antipodes, so today Joshua Swamidass is calling on us to consider the existence of genetic Antipodes.

\section{Unassailable facts Sometimes Require a Rethink}

As we all know, in 1492 Columbus sailed the ocean blue. Christendom came face to face with the fact that, not only do Antipodes exist, they are in the majority. The Bible is inerrant but we are not, and sometimes our interpretations and theological assertions are simply wrong.

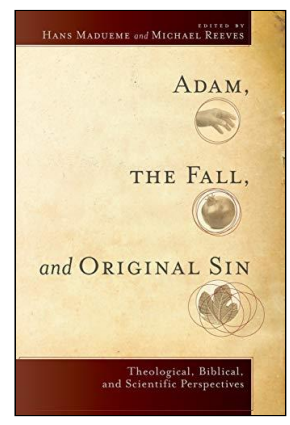

Historians point to a number of causes for the Enlightenment-which in many ways was a movement committed to the deliberate rejection of Christianity. One of the causes identified was the shock of discovering the new world. For many intellectuals of 16th and 17th centuries, the existence of Antipodes was further proof of the parochial nature of the Christian faith. How could belief in the necessity of responding to the gospel be held simultaneously with belief in the universal salvific will of God? If God truly desires the salvation of the inhabitants of the Americas, Asia and Africa, and if Explicit Faith is necessary for salvation, then why does it appear that he has been derelict in getting the message to the majority of humanity?

10. See Jeffrey Burton Russell, Inventing the Flat Earth: Columbus and Modern Historians (Westport: Praeger, 1991), 19-20; and David Livingstone, Adam's Ancestors: Race, Religion and the Politics of Human Origins (Baltimore: John Hopkins, 2008), 5-16.

11. Hans Madueme and Michael Reeves, Adam, the Fall, and Original Sin: Theological, Biblical, and Scientific Perspectives (Grand Rapids: Baker, 2014).

12. Ibid., 309. 
In his novel, Emile (1762), Jean-Jacques Rousseau expressed the Enlightenment revulsion against the notion of Explicit Faith. He imagines the response of an indigenous person who hears a missionary preach for the first time:

You announce to me God, born and dying, two thousand years ago, on the far side of the world, in some small town I know not where, and you tell me that all those who have not believed in this mystery will be damned. These are strange things to be believed so quickly on the authority of an unknown person. Why did your God make these things happen so far off, if he would compel me to know about them? Is it a crime to be unaware of what is happening half a world away? Could I guess that in another hemisphere there was a Hebrew nation and a town called Jerusalem? You might as well hold me responsible for knowing what is happening on the moon. ${ }^{13}$

\section{We've Lived with Ambiguity Before}

The point I'm making is that, when it comes to the doctrines of Original Sin and Explicit Faith, we've lived with ambiguity before. Consider Original Sin: Christians have universally agreed that Adam's sin brought about the fall of the human race, but beyond this there has been little real agreement. Did we participant in Adam's sin in some realist sense, or did Adam operate as some type of federal head? Are we born with a corrupted nature that inevitably sins, or are we born condemned and already under the judgment of God? And how and when is the remedy applied? Does baptism wash away Original Sin or are we delivered from Adam's stain at the time of conversion? These are not trivial questions, yet they still remain.

Similar questions surround the necessity of Explicit Faith. Christians universally agree that Christ is the one and only Savior of the world. But there's never been real agreement about the fate of the unevangelized. Typically three camps are recognized: Exclusivism, Inclusivism, and Pluralism. However, within each camp there are disagreements. Among exclusivists the question is about what exactly is the essential element. Is it the necessity of being incorporated into the Church, or is responding to the gospel that is necessary? Among inclusivists the debate is about how exactly the so-called "anonymous Christian" (Rahner's phrase) experiences saving grace. Is it a private matter (i.e., is he saved despite his religious errors)? Or is he saved in a more corporate manner (i.e., is grace somehow mediated through the non-Christian religions)? And as for Pluralists, they can't agree on what salvation is, so it's not surprising to find little agreement among them. We should not give the impression that the GAE model does damage to otherwise settled theological tenets.

\section{A Galaxy of Possible Interpretations}

The GAE model seems to have four strengths: First, it is compatible with a high view of Scripture and a fairly straightforward interpretation of Gen 1-11. Second, it is compatible with Adam and

13. Jean-Jacque Rousseau, Emile (New York: Dutton, 1969), 269.
Eve as the direct, miraculous de novo creation of God. Third, it is compatible with the belief that today all humanity struggles under the burden of Adam's disobedience. And fourth, it is compatible with the current scientific consensus that the universe and earth are ancient and that biological diversity is due primarily to speciation. (The mechanism of speciation and the nature of divine action in speciation are topics left for another day.)

As stated at the beginning, the most difficult aspect of the GAE model is that assumes that there were humans outside of the Garden. I'll be honest; I don't like it. However, I'm in a difficult position. I don't agree with my young-earth brethren when they basically reject the conclusions of practically every field of the natural sciences. And I can't go along with my evolutionist brethren who think a historical Adam can be discarded with relatively little consequence. I'm an oldearth creationist who believes that Adam and Eve were the special creation of God.

So my approach to the GAE model is similar to Augustine's approach to the creation account in Genesis. In his commentary on Genesis, Augustine admitted that he could not settle on one single interpretation, so he offered several possible interpretations. He imagined the irritated response of an exasperated reader:

Someone will say: "What have you brought out with all the threshing of this treatise? What kernel have you revealed? What have you winnowed? Why does everything seem to lie hidden under questions? Adopt one of the many interpretations which you maintain are possible."14

I suspect that some may find my paper similarly irritating because I argue that the GAE model should be held as one of several possibilities.

As it is, Old-earth Creationists seem to be taking three approaches. First, some move Adam as far back in time as necessary to make him the sole progenitor, not only of modern humans, but of all hominins. This requires some to date Adam as far back as 1.8 million years ago. ${ }^{15}$ Second, others point to some intermediate species that seem to demonstrate distinctly human activities such as creativity, symbolic reasoning or communication. The GAE model provides OEC with a third approach. Which of the three approaches is the best? At this point the conversation is very fluid.

\section{Conclusion}

We should note that the Church responded to the discovery of the broader world in an amazing and commendable way. The recognition resulted in the modern missions movement. Even though they couldn't quite square the discovery of Antipodes with the twin scandalous doctrines, those truths still guided their actions. From the Jesuits to the Moravians and the plethora of Protestant missionaries, they went about fulfilling the Great Commission. The new discoveries challenged them, but did not deter them. We should emulate them in this regard.

14. Augustine, The Literal Meaning of Genesis, (New York: Paulist Press, 1982), 1.21.41.

15. William Stone (a pseudonym), “Adam and Modern Science," in Adam, the Fall, and Original Sin (Grand Rapids: Baker, 2014), 80-81. 
The discussion surrounding the GAE model highlights something that many have missed: that the evolution/creation controversy has not been primarily about the mutability of species and speciation but rather about Original Sin. In the grand narrative of Creation, Fall, Redemption, and Consummation, the doctrine of the Fall plays a crucial role. As James K. S. Smith points out, the doctrine of Original Sin is not just about the what of the human condition, but also the how and the why. ${ }^{16}$ The doctrine of Original Sin doesn't simply teach that we are all sinners; it also explains how we became this way and why such a thing could happen in a world created by a good God.

Christians believe that the God who created the heavens and the earth is the God who gave us Christ and the Scriptures. This is why we work so hard to reconcile the findings of science with the teachings of

16. James K. S. Smith, "What Stands on the Fall? A Philosophical Exploration," in Evolution and the Fall, William T. Cavanaugh and James K. S. Smith, eds. (Grand Rapids: Eerdmans, 2017), 49.

\section{References}

S. Joshua Swamidass, The Genealogical Adam and Eve, 2019.

Gabriel Fackre, “The Scandals of Particularity and Universality," Midstream 22:1 (Jan 1983).

Hans Madueme, "Evolution and Historical Adam? A Provocative but Unconvincing Attempt,” The Gospel Coalition (March 2, 2020). https://www.thegospelcoalition.org/reviews/genealogical-adam-eveswamidass/ (Accessed 11/12/20)

Lactantius, Divine Institutes, 3.24; and Cosmas, Christian Topography, Book 4.

Augustine, The City of God.

Isidore, Etymologies.

Aquinas, Disputed Questions on Truth.

William Lane Craig, “'No Other Name’: A Middle Knowledge Perspective on the Exclusivity of Salvation through Christ," Faith and Philosophy 6:2 (April 1989): 174.
Scripture. We believe they are compatible, or at least congruent. In this sense, all good Christians are Concordists.

Because of these confessional affirmations, I also admit that I expect a resolution of some type. Yes, there will always be that which we don't understand and areas that seem to be incongruent. Yet there should be the broad outlines of an overall agreement. This expectation on my part-this desire-carries with it its own dangers. Will I become overeager? Will I latch on to proposed solutions for which I should have been more cautious? There are plenty of examples in the past where just such a thing happened, so I must let history speak to me.

It's worth noting that Swamidass himself presents the GAE model simply as a possible solution, and that he does not commit himself to GAE. Therefore I see no reason to commit myself more strongly that he does. But I do believe it deserves recognition as a viable hypothesis, worthy of further research. Let the conversation continue.

Jeffrey Burton Russell, Inventing the Flat Earth: Columbus and Modern Historians (Westport: Praeger, 1991), 19-20

David Livingstone, Adam's Ancestors: Race, Religion and the Politics of Human Origins (Baltimore: John Hopkins, 2008), 5-16.

Hans Madueme and Michael Reeves, Adam, the Fall, and Original Sin: Theological, Biblical, and Scientific Perspectives (Grand Rapids: Baker, 2014).

Augustine, The Literal Meaning of Genesis, (New York: Paulist Press, 1982).

William Stone (a pseudonym), “Adam and Modern Science," in Adam, the Fall, and Original Sin (Grand Rapids: Baker, 2014), 80-81.

James K. S. Smith, "What Stands on the Fall? A Philosophical Exploration," in Evolution and the Fall, William T. Cavanaugh and James K. S. Smith, eds. (Grand Rapids: Eerdmans, 2017). 